\title{
CHEMICALLY MODIFIED SURFACES FOR THE SEPARATION OF NON-POLAR ORGANIC CONTAMINANTS FROM THE WATER
}

\author{
By \\ Nadeem Baig*1,2, Tawfik A. Saleh ${ }^{1}$ \\ 'Chemistry Department, King Fahd University of Petroleum and \\ Minerals, Dhahran 31261 , Saudi Arabia. \\ ${ }^{2}$ Center for Research Excellence in Desalination \& Water \\ Treatment, King Fahd University of Petroleum and Minerals, \\ Dhahran 31261 , Saudi Arabia
}

* Corresponding author

Email: nadeembaig@kfupm.edu.sa; nadeembaig38@gmail.gom 


\section{CONTENTS}
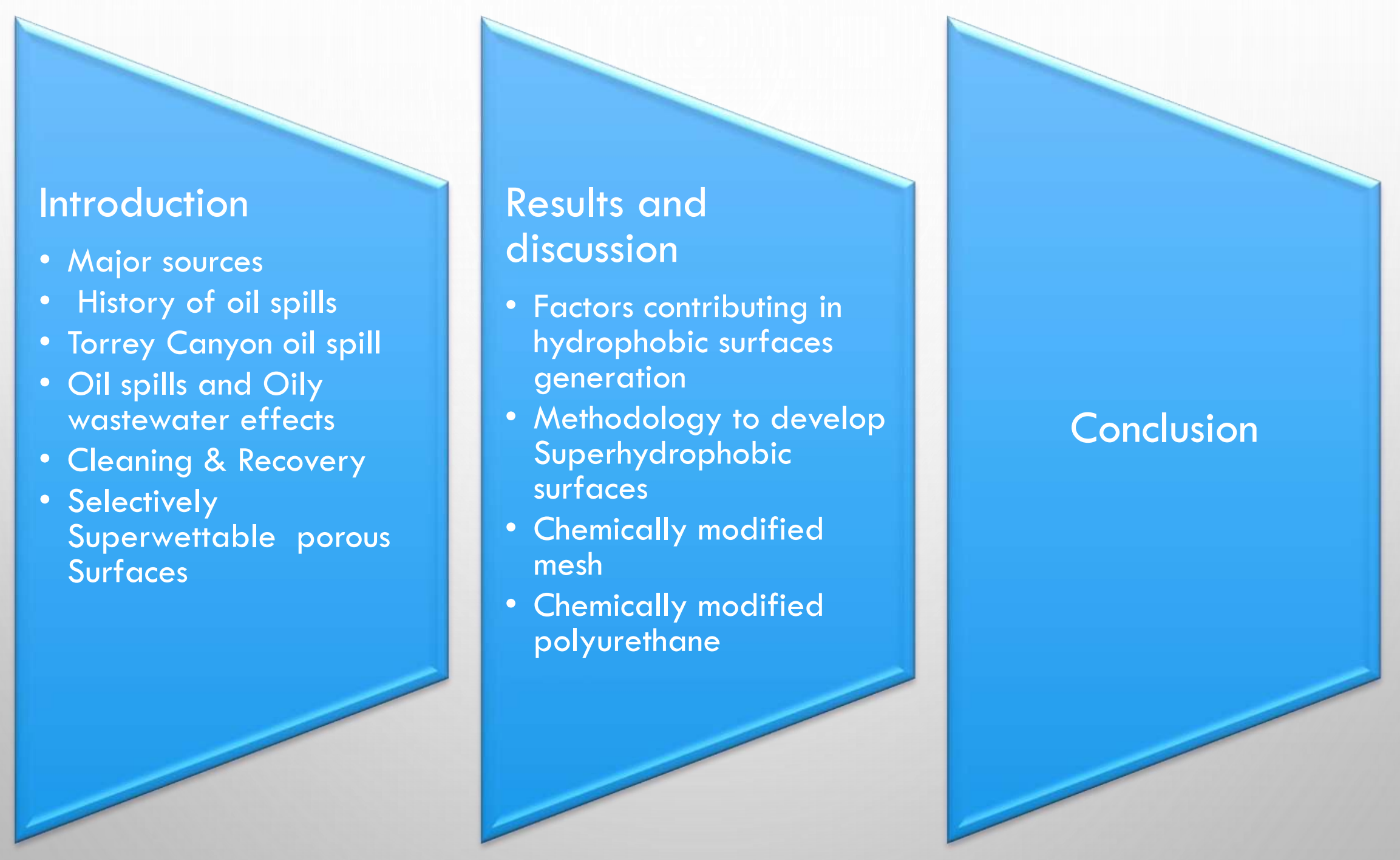


\section{MAJOR SOURCES OF ORGANIC POLLUTION IN WATER}

Industries According to an estimation on daily basis 33.6 million barrels oil contaminated water released

Agricultural pollution

\section{Oil spills}

\section{Household activities}

Afzal, M.; Rehman, K.; Shabir, G.; Tahseen, R.; ljaz, A.; Hashmat, A. J.; Brix, H. npj Clean Water 2019, 2 (1), 3. 


\section{MAJOR OIL SPILLS}

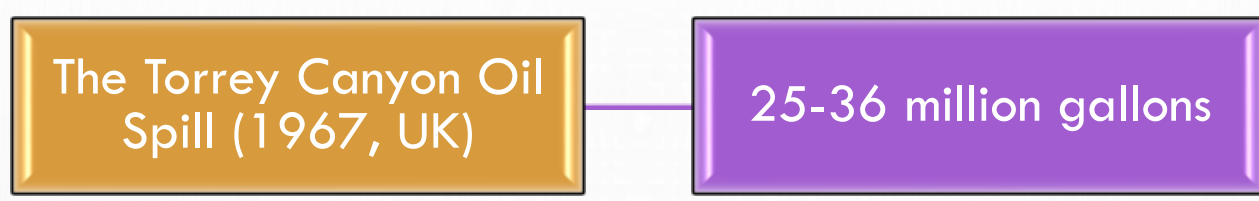

The Sea Star Oil Spill
(1972, Gulf of Oman)

35.3 million gallons
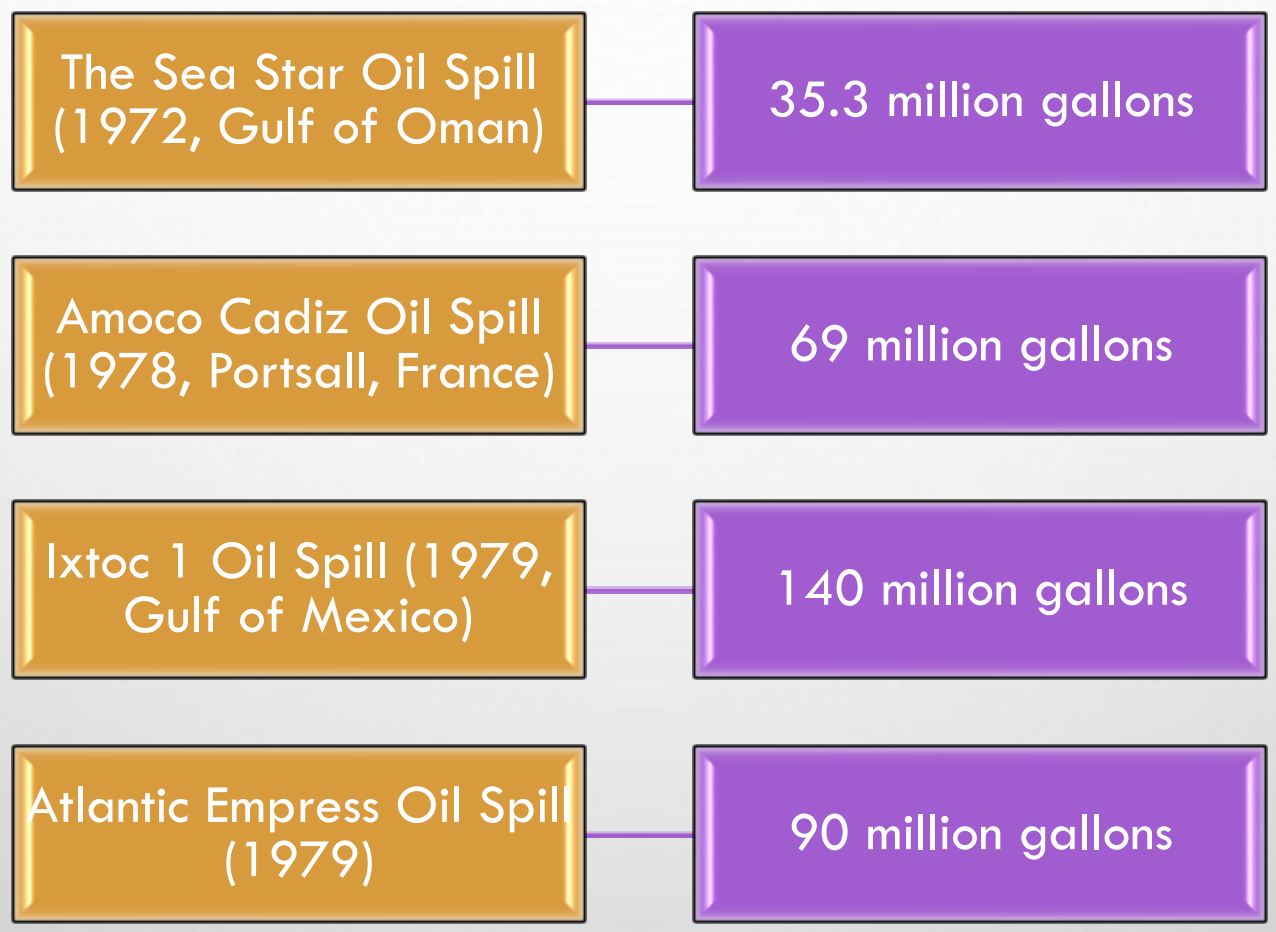

Nowruz Oil Field Spill 1983, Persian Gulf, Iran

80 million gallons

https://www.mnn.com/earth-matters/wilderness-resources/stories/the-13-largest-oil-spills-in-history 


\section{MAJOR OIL SPILLS}
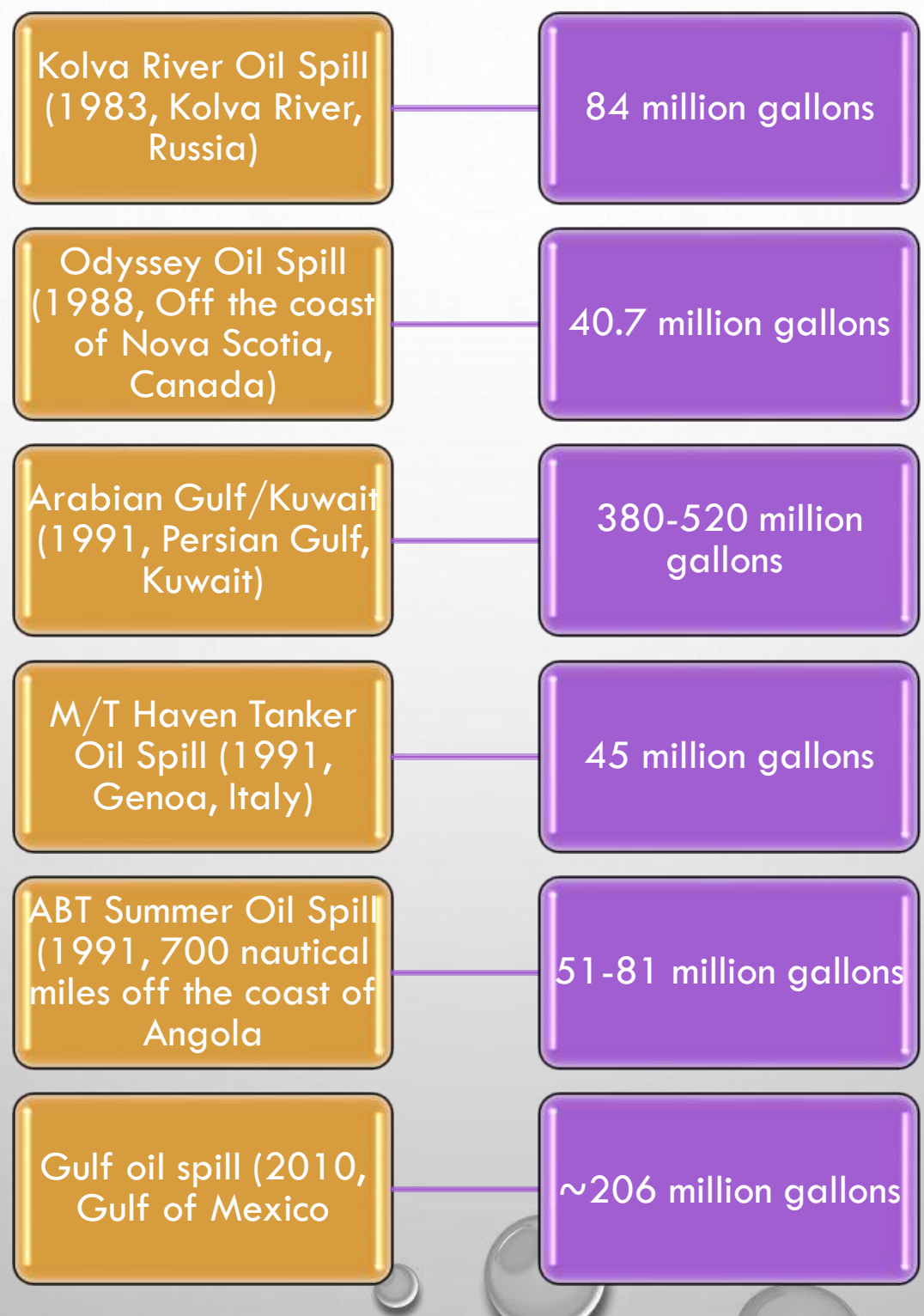

https://www.mnn.com/earth-matters/wilderness-resources/stories/the-13-largest-oil-spills-in-history 


\section{TORREY CANYON OIL SPILL}

Torrey Canyon capacity was 60,000 to 120,000 tons of oil

Torrey Canyon was carrying the 119,000 tons of crude oil on the day of accidents

On accident more than 100,000 tonnes of crude oil spilled

on Cornwall beaches 14,250 tons of oil was treated by 10,200 tons of detergents

2 million gallons BP 1002

Used Detergents containing Aromatic hydrocarbons in high proportion about $62 \%$

$>15,000$ sea birds

$85 \%$ puffins killed

Effect of spills remain for years

1. Law, R. J. The Torrey Canyon Oil Spill, 1967. In Oil Spill Science and Technology; Elsevier, 2011; pp 1103-1106.

2. hitps://www.bbc.com/news/uk-england-39223308, 2017 


\section{OIL SPILLS AND OILY WASTEWATER EFFECTS}

Severely affecting the water resources

Exposure to oil contaminated water is Jeopardizing the human and aquatic life

Oil containing water irrigation can affect the crop production

Volatile components increasing the atmospheric pollution

Chemicals based cleaning of oil spilled water can further exacerbate the water and environmental pollution

Huge quantity of chemicals are required for cleaning that make overall process expensive

Yu, L.; Han, M.; He, F. A Review of Treating Oily Wastewater. Arab. J. Chem. 2017, 10, S1913-S1922. 


\section{CLEANING \& RECOVERY OF THE OIL CONTAMINATED WATER}

\section{Oil Spill Effect:}

The oil contaminants may persist at the place of incidents for long time and their effect can be sensed for years. The efforts are required to clean and recover the aquatic system. The clean and recovery can be defined as in context of oil spills.

\section{Clean}

Cleaning of an ecosystem in case of oil spill can be defined as the coming back of the petroleum hydrocarbons to a level that display no detectable impact on the ecosystem.

\section{Recovery}

Recovery of an ecosystem is defined as the restoration of a biological community such as plants and animals' like before the incident are present and ecosystem start to function normally

Kingston, P. F. Long-Term Environmental Impact of Oil Spills. Spill Sci. Technol. Bull. 2002, 7 $(1-2), 53-61$. 
SELECTIVELY SUPERWETTABLE POROUS SURFACES FOR SEPARATION OF NON-POLAR ORGANIC CONTAMINANTS FROM THE WATER

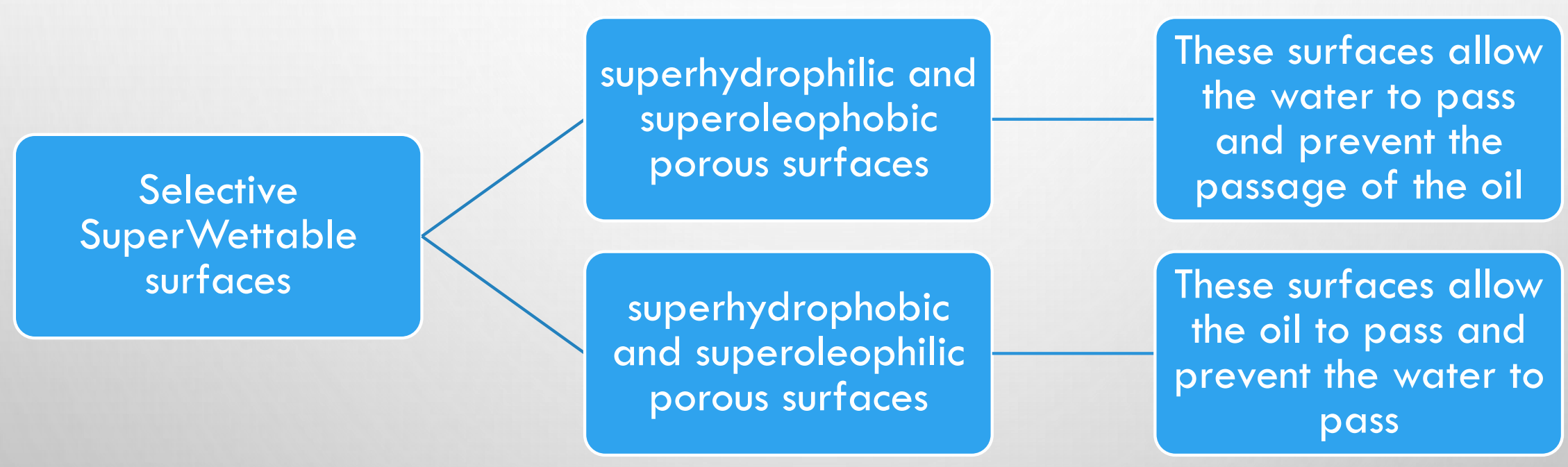

Peng, Y.; Guo, Z. Recent Advances in Biomimetic Thin Membranes Applied in Emulsified Oil/Water Separation. J. Mater. Chem. A 2016, 4 (41), 15749-15770. 
00

\section{RESULTS \& DISCUSSIONS}

CHEMICALLY MODIFIED SUPERHYDROPHOBIC SURFACES FOR SEPARATION OF NON-POLAR CONTAMINANTS 


\section{FACTORS CONTRIBUTING IN THE GENERATION OF HYDROPHOBIC SURFACES FOR SEPARATION}

- POROUS NETWORK

- THE DEVELOPMENT OF SUITABLE POROUS NETWORK IS MANDATORY THAT HELP IT FILTRATE OR ABSORB THE TARGETED CONTAMINANTS FROM WATER

- SURFACE ENERGY

- SUITABLE POROUS NETWORK MODIFICATION WITH LOW SURFACE ENERGY

- SURFACE ROUGHNESS

- SURFACE ROUGHNESS PLAY AN IMPORTANT ROLE TO ACHIEVE SUPERHYDROPHOBIC SURFACES 


\section{METHODOLOGY TO DEVELOP SUPERHYDROPHOBIC SURFACES}

Suitable porous network
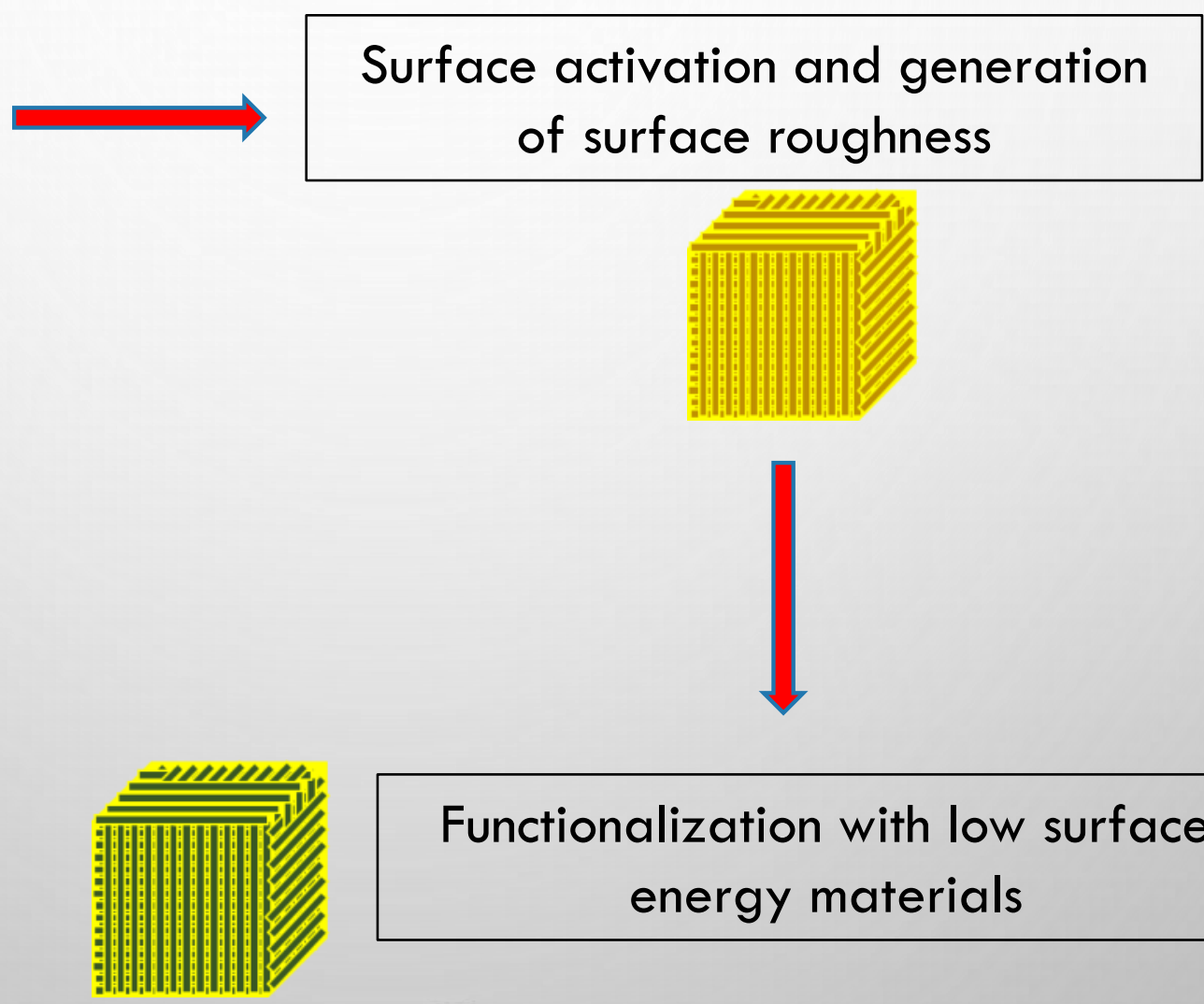

Functionalization with low surface energy materials 


\section{CHEMICALLY MODIFIED SUPERHYDROPHOBIC MESH}


Meshes display good mechanical stability

Meshes are good choice for the separation and filtration applications for number of reasons

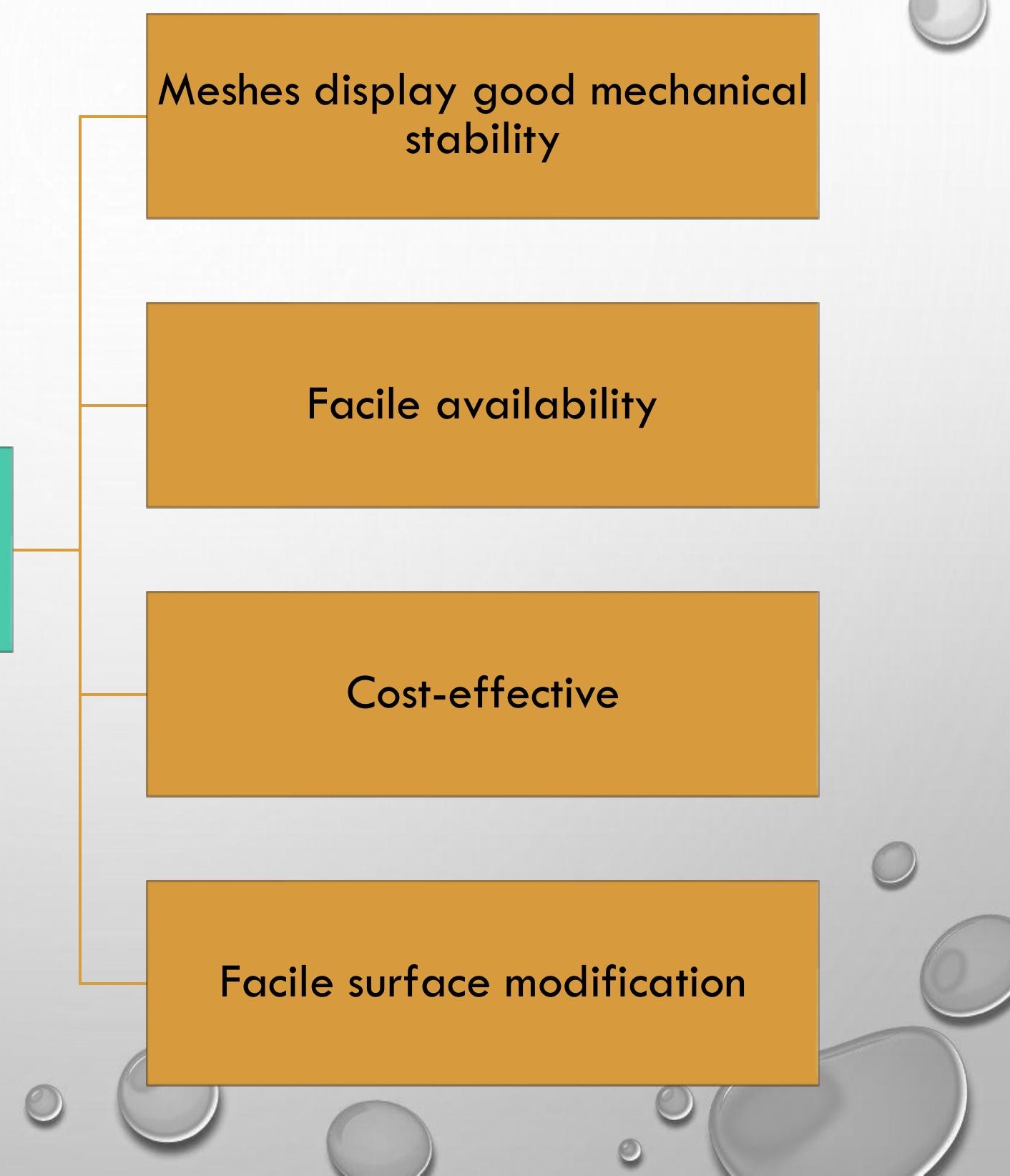


MESH INITIAL TREATMENT

AND

ACTIVATION
Mesh treated with sevral liquids

Water and acetone for cleaning

Sulfuric acid treatment to activate surface and generate surface rougness

Saleh, T. A.; Baig, N. Prog. Org. Coatings 2019, 133, 27-32. 


\section{STAGE WISE SURFACE MORPHOLOGY OF THE $M E S H$}

1. MESH FIBER BEFORE ACID TREATMENT

2. MESH FIBERS AFTER TREATMENT TO ACHIEVE SURFACE ROUGHNESS AND ACTIVATION

3. MODIFICATION WITH LOW SURFACE ENERGY MATERIALS

Saleh, T. A.; Baig, N. Prog. Org. Coatings 2019, 133, 27-32. 


\section{MESH HYDROPHOBICITY IMPROVED BY LOW SURFACE ENERGY MATERIAL}

\section{Mesh} water contact Angles

(B) After treatment

(C) After low surface energy material modification

(A) Before treatment

$$
\mathrm{CA}=114.8^{\circ}
$$

(A)

$$
\mathrm{CA}=68.5^{\circ}
$$

(B)

Saleh, T. A.; Baig, N. Prog. Org. Coatings 2019, 133, 2732. 


\section{APPLICATION AND SEPARATION EFFICIENCY OF MESH}

- THE MODIFIED MESH REPELLED WATER AND DROP OF WATER FREELY MOVED ON THE SURFACE OF THE MESH.

- THE NON-POLAR COMPONENT RAPIDLY SPREAD AND PASSED THROUGH THE PORES OF THE MESH

- THE SEPARATION EFFICIENCY FOR THE VARIOUS NON-POLAR ORGANIC COMPONENTS FROM WATER WAS ATTAINED MORE THAN $99 \%$

Saleh, T. A.; Baig, N. Prog. Org. Coatings 2019, 133, 27-32. 
CHEMICAL MODIFICATION OF POLYURETHANE

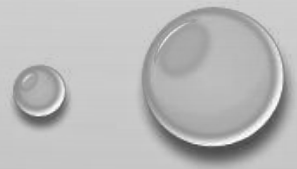




\section{POLYURETHANE ATTRACTIVE FEATURES}

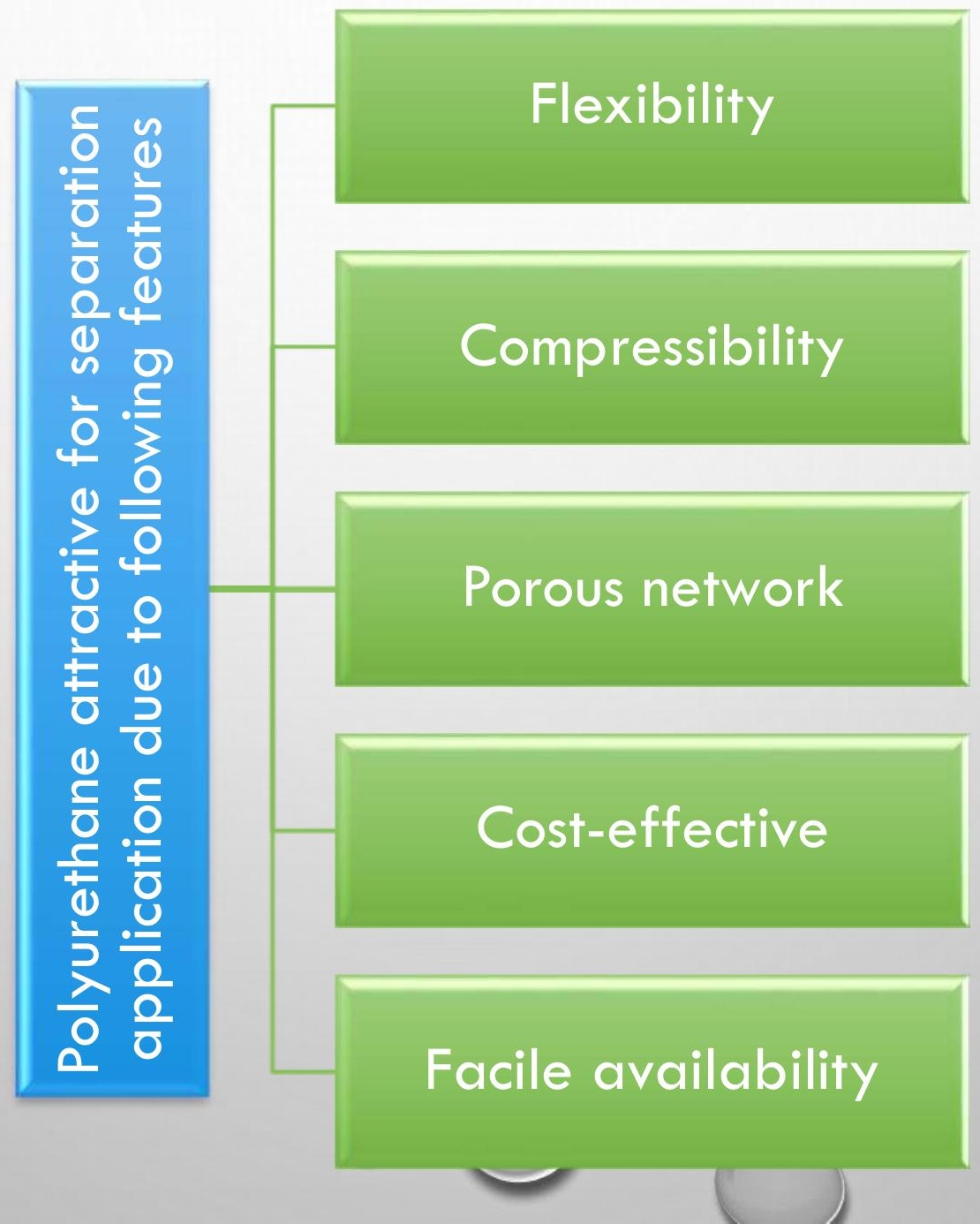




\section{MODIFICATION STEPS OF POLYURETHANE}

\section{Modification steps}

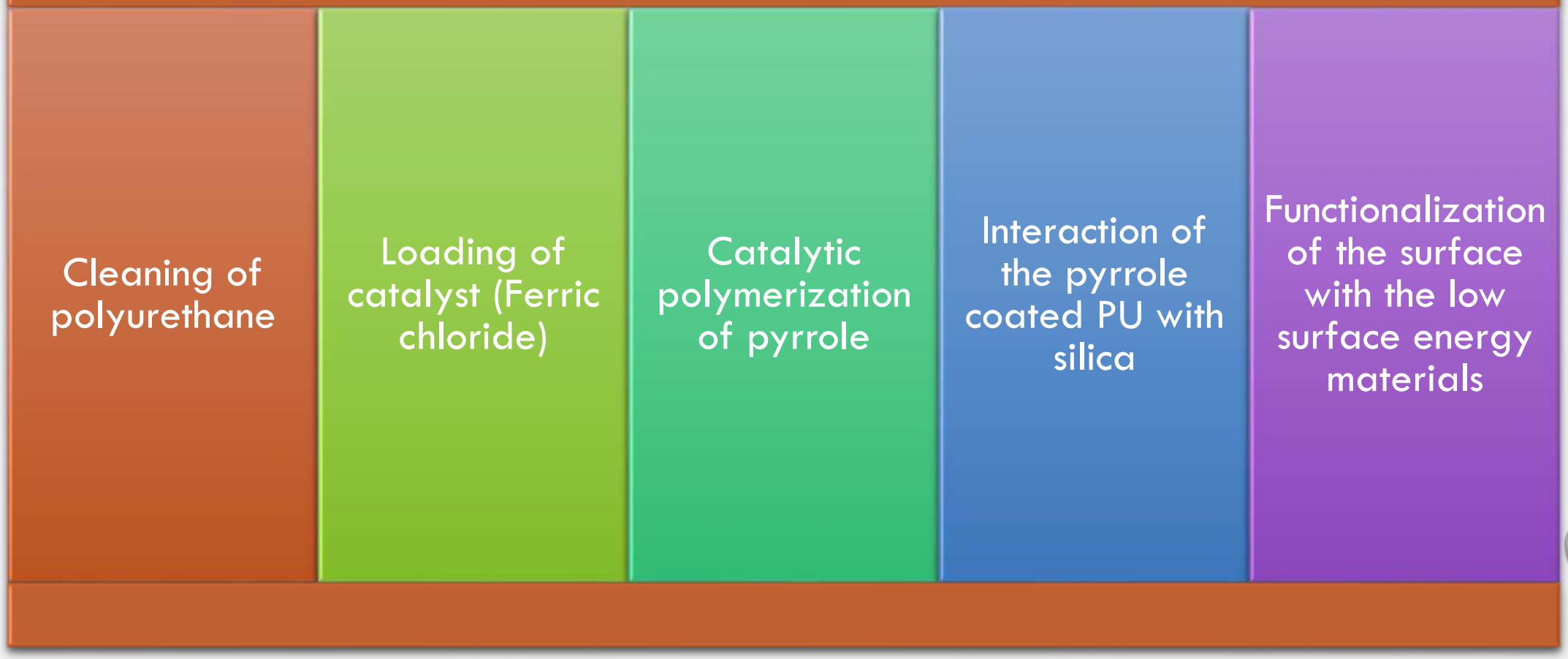

Saleh, T. A.; Baig, N.; Alghunaimi, F. I.; Aljuryyed, N. W. RSC Adv. 2020, 10 (9), 50885097. https://doi.org/10.1039/C9RA06579B. 


\section{SEM IMAGES DESCRIBING STEPWISE SURFACE CHANGES}

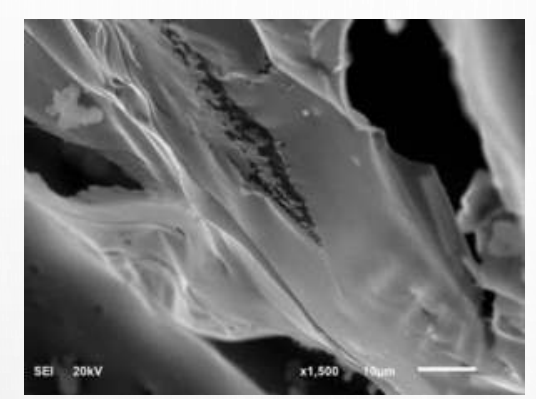

PU prior to modification
Step 1

Catalyst loading

Step 2

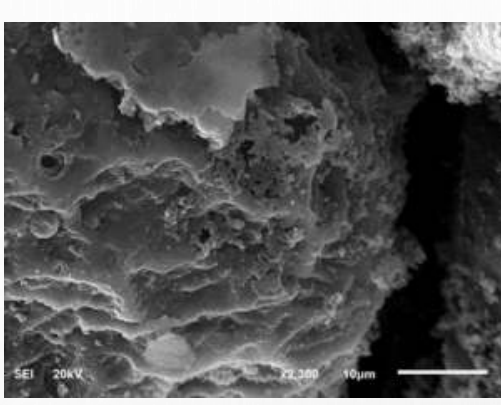

Pyrrole modification

Step 3

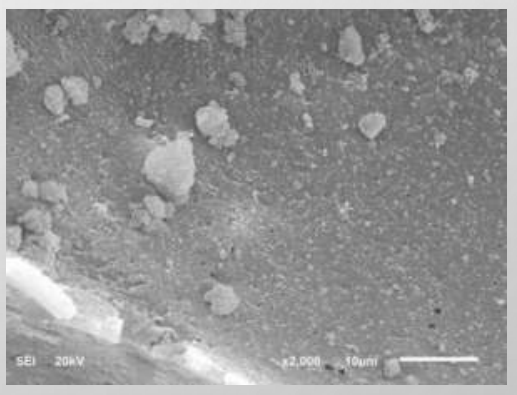

After Silica modification

After low surface energy material modification

Step 4

Saleh, T. A.; Baig, N.; Alghunaimi, F. I.; Aljuryyed, N. W. RSC Adv. 2020, 10 (9), 5088-5097. 


\section{FTIR SPECTRA OF UNMODIFIED AND MODIFIED PU}

PU FTIR prior to modification

PU FTIR after modification with polypyrrole, silica and Octadecyltrichlorosilane

The presence of relevant functional group absorption band has confirmed the successful functionalization of the PU surface
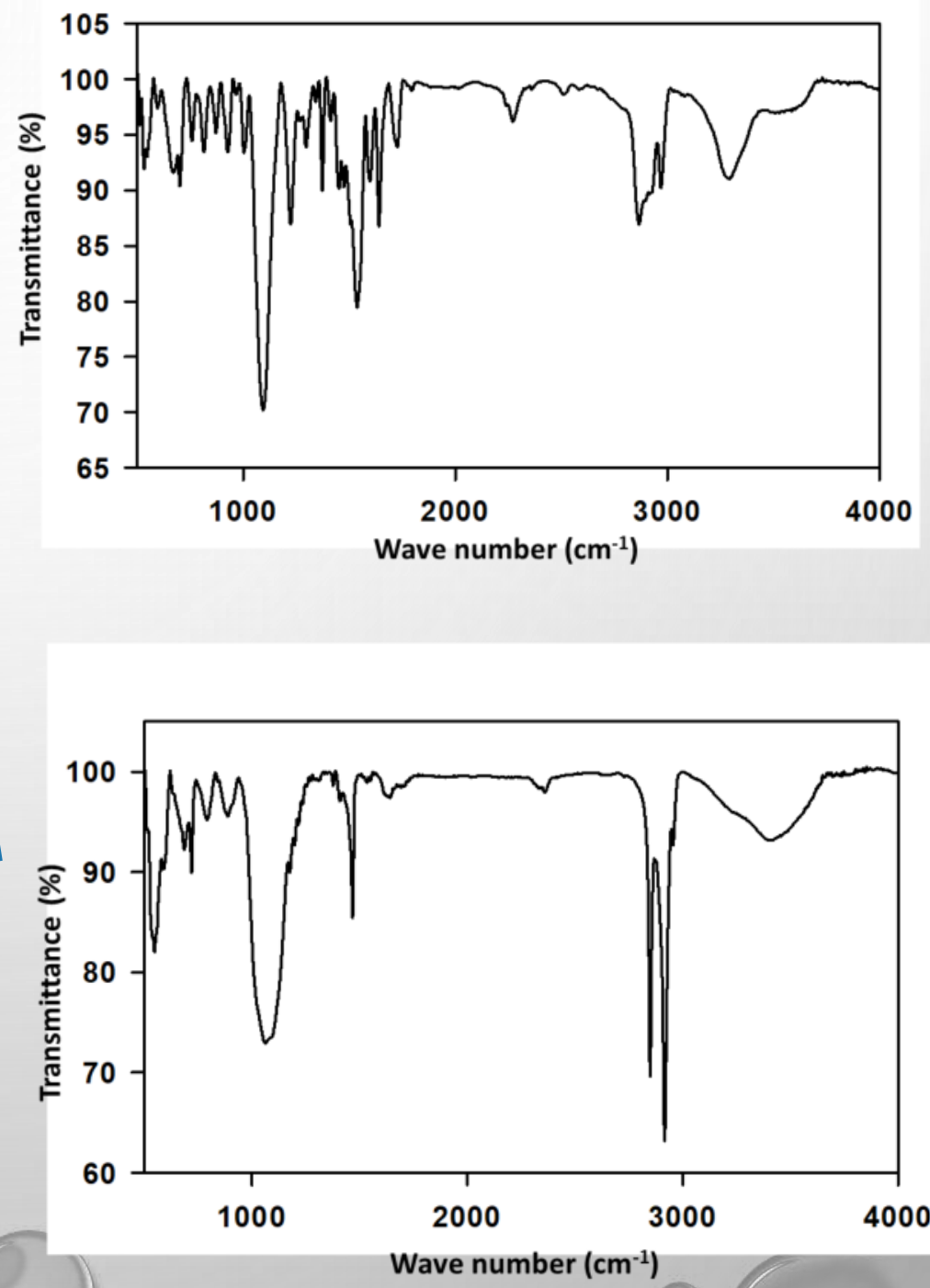

Saleh, T. A.; Baig, N.; Alghunaimi, F. I.; Aljuryyed, N. W. RSC Adv. 2020, 10 (9), 5088-5097. 


\section{WATER CONTACT ANGLE BEFORE AND AFTER MODIFICATION}

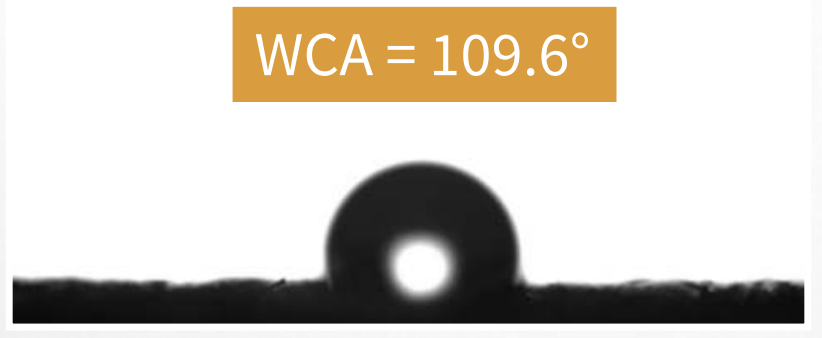

Water contact angle before modification

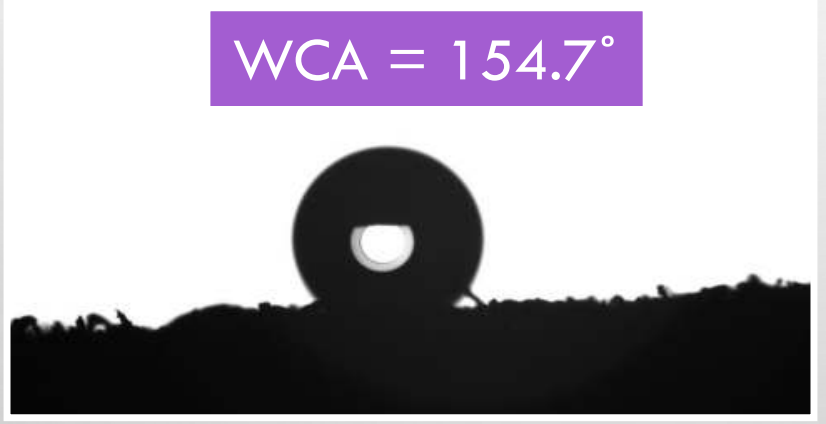

Water contact angle after modification

Saleh, T. A.; Baig, N.; Alghunaimi, F. I.; Aljuryyed, N. W. RSC Adv. 2020, 10 (9), 5088-5097. 


\section{ABSORPFION CAPACITY OF MODIFIED POLYURETHANE FOR VARIOUS NON-POLAR COMPONENTS}

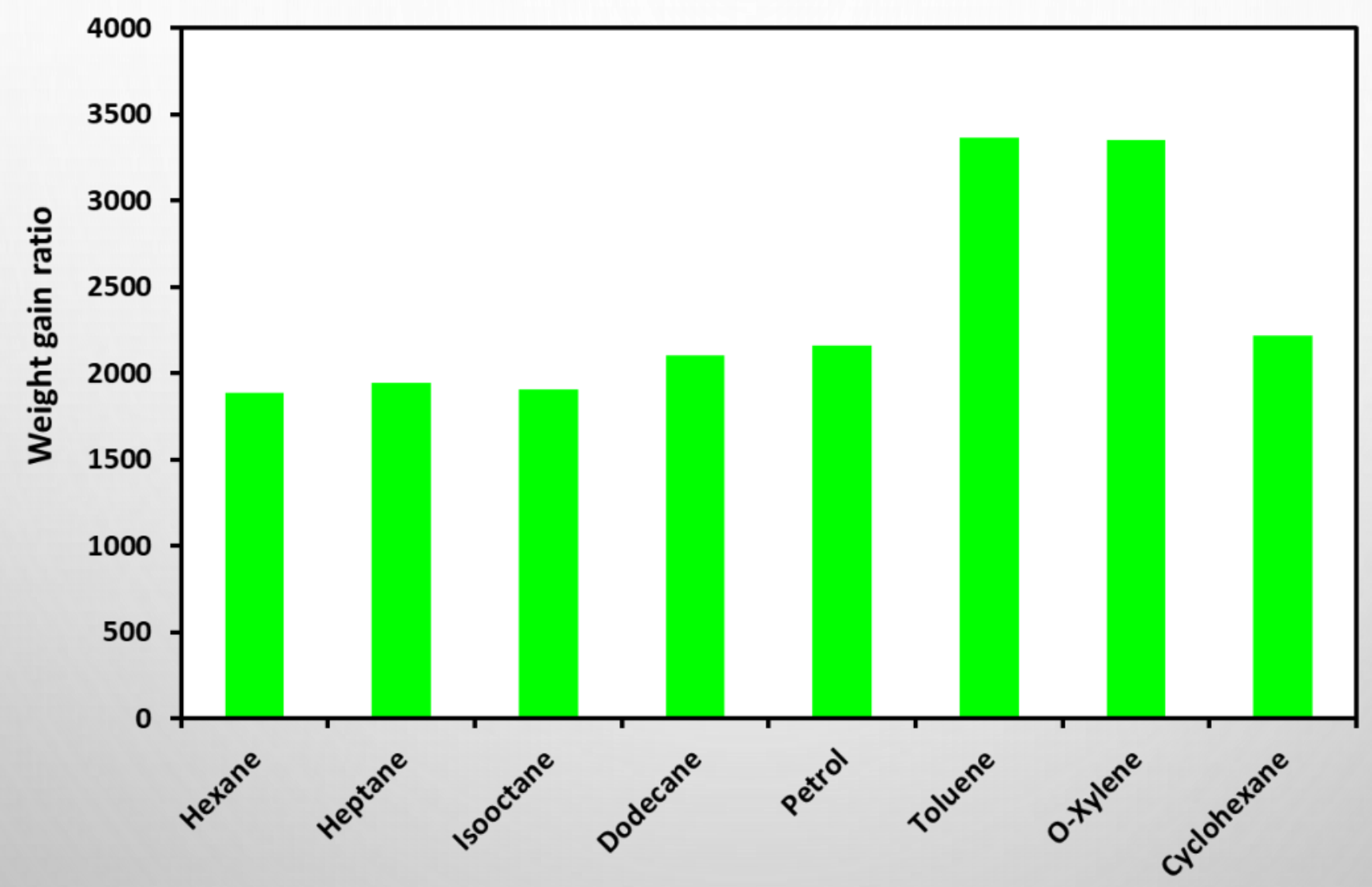

Saleh, T. A.; Baig, N.; Alghunaimi, F. I.; Aljuryyed, N. W. RSC Adv. 2020, 10 (9), 5088-5097. 


\section{SEPARATION OF SURFACTANT FREE EMULSIONS (WATER IN OIL)}

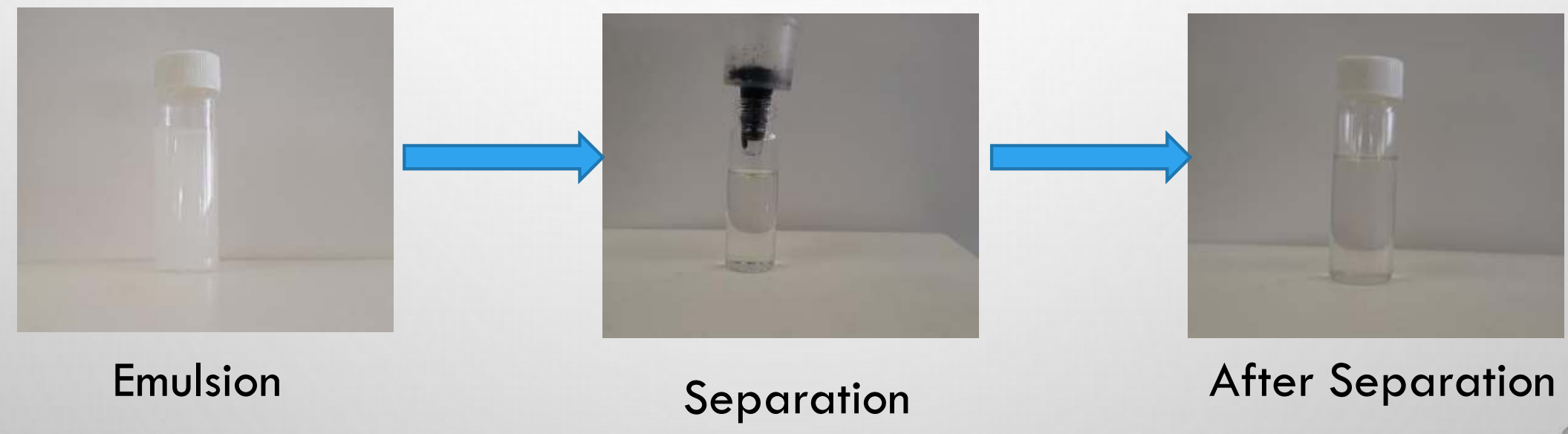

Saleh, T. A.; Baig, N.; Alghunaimi, F. I.; Aljuryyed, N. W. RSC Adv. 2020, 10 (9), 5088-5097. 


\section{FASCINATING FEATURE OF CHEMICALLY MODIFIED POLYURETHANE}

DMODIFIED POLYURETHANE HAS DISPLAYED ABSORPTION CAPACITY IN THE

RANGE OF 18 TO 34 TIMES TO ITS OWN WEIGHT

DEXCELLENT REGENERATION FOR HEXANE (RSD $= \pm 0.7)$, DODECANE( \pm 1.2$)$

AND PETROL ( \pm 2.9$)$

MMODIFIED POLYURETHANE HAS REVEALED HIGH FLUX FOR HEXANE

DMODIFIED POLYURETHANE IS EFFECTIVE FOR THE SEPARATION OF THE

EMULSIONS

Saleh, T. A.; Baig, N.; Alghunaimi, F. I.; Aljuryyed, N. W. RSC Adv. 2020, 10 (9), 5088-5097. 


\section{CONCLUSION}

Meshes are mechanically stable

Activation of mesh surface achieved through facile method

Modification process is easy

Meshes can only used for filtration process

Polyurethane provide opportunity for both absorption and separation application

Chemically modified surfaces of mesh and polyurethane selective towards nonpolar organic contaminates from water

These materials are Cost-effective and provide chances for scale up
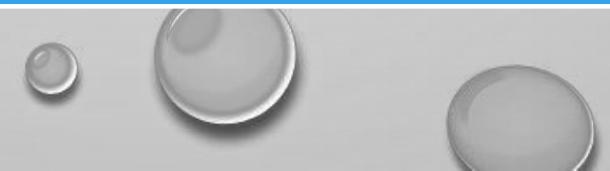


\section{ACKNOWLEDGEMENT}

Authors gratefully acknowledge the support provided by the "King Fahd University of Petroleum and Minerals, Dhahran, Saudi Arabia". 